\title{
Parental migration and the educational enrolment of left-behind children: Evidence from rural Ponorogo, Indonesia
}

Silvia Mila Arlini (National University of Singapore)

Brenda S.A. Yeoh (National University of Singapore)

Khoo Choon Yen (National University of Singapore)

Elspeth Graham (University of St Andrews, UK)

\begin{abstract}
This paper examines the effects of parental migration on children's educational enrolment following the recent reforms in Indonesian educational policy. We find that, in general, parental migration has a positive impact on school enrolment, although this varies by the child's age and the gender of the migrant parent. Parental migration has an adverse impact on the school enrolment of younger children who are eligible for free education, but a positive impact on older children who are no longer able to access state educational support. The gender of the migrant parent matters, as paternal migration appears to have a more positive impact on children's educational enrolment than maternal migration. Maternal migration is associated with a reduction of younger children's likelihood of a being in school, while paternal migration makes no difference to their school enrolment. For older children, maternal migration has a lower positive impact compared to paternal migration. Our qualitative interviews also show mixed findings: some children appreciate their migrant mothers' migration efforts and are motivated to persevere in continuing education, while others are weighed down by their migrant mothers' sacrifice and develop a sense of obligation to reduce their financial burdens by leaving education early to enter paid employment.
\end{abstract}

Key words: parental migration, left-behind children, education enrolment, public education support, gender roles, Indonesia 


\section{Introduction}

Parent-child separation due to parental migration is increasingly common in developing countries in Southeast Asia (Asis, 2006; Nguyen, Yeoh and Toyota, 2006; Zimmer \& Van Natta, 2018), where labour migration has become an important strategy for improving livelihood and enhancing socio-economic status. The number of children growing up with one or no co-resident parent(s) is increasing, especially in rural areas where the incidence of temporary out-migration is higher. Southeast Asian parents generally consider upper secondary and tertiary education as an important prerequisite for securing reasonable and good paying jobs (Suryadarma \& Jones, 2013), where higher education attainment is expected to significantly increase access to formal jobs (Manning \& Pratomo, 2013) and open pathways toward upward socio-economic mobility. Hence, parents often justify the socio-emotional costs of separation during their migration by referencing future gains such as increased financial support for their children in later life. Emotional costs of parental migration may be ameliorated by the economic benefit generated from remittances that potentially provide more resources for children to continue higher education (Arguillas \& Williams, 2010).

There has been much debate in the scholarly literature on the overall net effect of parental migration on left-behind children's educational outcomes. Scholars working in the Latin American context have tended to argue that long-term separation resulting from the international migration of parent(s) has an adverse effect on children's educational outcomes (Creighton, Park, \& Teruel, 2009; McKenzie \& Rapoport, 2011; Lu, 2014) while those referencing the Southeast Asian context have tended to yield more positive outcomes. Jordan and Graham (2012), for example, showed that children across Southeast Asia generally adjusted well to their parents' long-term absences as seen in school outcomes, while Asis and Ruiz-Marave (2013) found that Filipino parental 
migration, especially mother migration, positively influenced children's school outcomes. Similarly, Hoang, Lam, Yeoh \& Graham (2015) found that Vietnamese children of international migrant parent(s) appreciated their parents' sacrifice and resolved to behave well and study hard to make good that sacrifice. In the Indonesian context, $\mathrm{Lu}$ (2014) found that the international migration of parent(s) had a marginally adverse impact on children's schooling, while Nguyen and Purnamasari (2011) found that parental migration did not significantly affect children's schooling.

This paper focuses on the rural Indonesian context and contributes to understanding the effects of parental migration on left-behind children's educational enrolment by interrogating a number of key factors: i.e. gender of the migrant parent, household characteristics (socio-economic condition and family composition) and, most importantly, children's age (in order to distinguish those eligible for compulsory education benefits). In light of the fact that much of the current literature on migration and children's educational outcomes in Indonesia (e.g. Lu, 2014, Nguyen \& Purnamasari, 2011, Parinduri \& Tangavelu, 2011) has not given sufficient attention to how state policy on public education support mediates this relationship ${ }^{1}$, we follow other scholars (Suharti, 2013; Al-Samarrai \& Cerdan-Infantes, 2013; Post \& Pong, 1998) who have argued that educational policy infrastructure, such as free schooling and education subsidies, helps to reduce inequality in accessing education.

In Indonesia, the first nine years of compulsory basic education are heavily subsidised by the state since the implementation of the Law on National Education (No. 20/2003) and the Constitution Amendment III (PP 47/2008). This paper is interested in understanding the effects of parental migration on children's education enrolment in the context of recent developments such as the Indonesian state's investment in a universal 
nine-year compulsory basic education programme. The paper provides evidence pointing to the importance of considering educational policy infrastructure when unpacking the impacts of migration on children's education.

The paper begins with a selected review of the background literature that frames our analysis of the relationships between children's school enrolment, parental migration and education support. After a discussion of our field-site in rural Ponorogo and the methods and data used, the paper draws on the key findings to provide deeper insights into the links between parental migration, educational infrastructure and the educational impact on left-behind children.

\section{Parental migration, public education support and children's education}

The migration literature suggests that the impact of parental migration on leftbehind children is highly complex. More specifically, with Southeast Asia witnessing more opportunities for women to access work through international migration, the literature suggests that it is crucial to consider the gender of migrant parents when assessing the impact of migration on children (Dreby \& Stutz, 2012). Studies have shown that migrant mothers tended to invest more in children's education compared to migrant fathers (Hu, 2013; Rahman \& Lian, 2009), and that emotional support may be provided by the left-behind father and other caregivers in the mother's absence (Lam \& Yeoh, 2016). However, children tended to better appreciate their fathers' breadwinning role through overseas migration and preferred their mothers to be stay-home caregivers (Asis, 2006; Parreñas, 2008) as this entailed less disruption to the pre-existing household division of labour. Despite changing family practices in many parts of the world, the roles of mothers and fathers are still perceived in a distinct way in most of developing Asia. When fathers migrate, left-behind mothers continue their socially inscribed role of 
carers/nurturers of their children within the existing nuclear family structure (Khoo, Platt, \& Yeoh, 2017); when mothers migrate, left-behind fathers often struggle to shoulder the nurturing role and additional housework alongside working outside the home in order to remain 'productive' and uphold their masculine identities (Lam \& Yeoh, 2016).

Some studies on Asian migration have teased out the differential socio-emotional impacts of migration on source communities according to the gender of the migrant parent, arguing that the migrant parent's absence changes the family structure and caregiving arrangements (Cortes, 2015; Asis \& Ruiz-Marave, 2013; Jampaklay, 2006; Parreñas, 2001). In the Philippines, Asis and Ruiz-Marave (2013) found that, while children in transnational households were not worse off than those living with nonmigrant parents in terms of school pacing and achievement, those with a migrant father and mother carer fared the best as this arrangement 'combine[d] the possibility for families and households to increase their economic resources and the continuation of the caregiving role of mothers' (pp. 371-2). Left-behind fathers are commonly observed to spend less time engaged in caring for their children (Lam \& Yeoh, 2014). Cortes (2015) found evidence that Filipino children with migrant mothers were more likely to lag behind in their schooling compared to children of migrant fathers or non-migrant parents. Parreñas' findings (2001) emphasised the emotional ramifications of migrant mothers on children left behind, suggesting that traditional notions of mothering continue to be present in mother-migrant families. She argued that mothers' participation in overseas migration to maximise the economic benefits for the households are often overshadowed by the onus of responsibility for emotional care being solidly placed in the hands of women. Similarly, in the Thai context, Jampaklay (2006, p. 93) observed that 'the mother's roles are not easily replaced by other family members insofar that the long-term absence of mothers reduce[d] the educational chances of children left behind', but not so 
for father's absence.

A caveat to the above-mentioned studies is that they tend not to detail the availability and extent of public education support. Nearly all Southeast Asian countries have implemented compulsory education policies and legislated free education for at least nine years ${ }^{2}$ (UNESCO, 2017). Nevertheless, previous studies have usually not given consideration to the impact of public educational support in the migration context, particularly how it mediates the impact of parental migration on left-behind children's education. For Indonesia, there have been several descriptive studies which have investigated the impact of the state's investment in universal nine-year compulsory basic education. Suharti (2013) and Al-Samarrai and Cerdan-Infantes (2013) illustrated how the government's funding to support the compulsory basic education programme has increased access to basic education for children in rural areas and for children in poorer households, and has raised girls' school attendance rates to levels similar to that for boys. However, questions remain over the equity of the state's increased educational investments, as it was also observed that children from the poorest income quintile were being left out.

The literature above provides a starting point for our investigation of the impact of parental migration on children's school enrolment in Indonesia in the light of recent changes in the Indonesian education system. This fills a gap in the literature as there is, to-date, little systematic empirical research that allows for close examination of how leftbehind children in rural Indonesia fare in education, with specific attention to distinguishing children from different age cohorts who necessarily benefitted differently from current state-supported education policies. As our interest is in whether the implementation of the education policies leads to differences in the effect of parental 
migration on children's education according to level of schooling, our analysis distinguishes two age cohorts: first, younger children in basic education (primary and lower secondary), aged 7-15, and second, older children in upper secondary school and above, aged 16-21. We also distinguish between the effects of maternal migration and paternal migration on children across different age cohorts, and incorporated the impacts of household characteristics, to understand exacerbating or limiting effects on children's educational enrolment. In sum, this study addresses two main research questions:

1. Does parental migration influence children's educational enrolment, and does the influence vary by the gender of the migrant parent?

2. Does the influence vary by child age-cohort (by their eligibility for free compulsory basic education)?

\section{Research hypotheses}

We consider three hypotheses for our analysis. First, reflecting on the possible material benefits of parental migration and the rural economy setting of the study where resources for supporting children's education are relatively limited, we expect that parental migration is positively associated with children school enrolment. Hanson and Woodruff (2003) using Mexican data showed that children in rural migrant households complete more years of education than those in non-migrant households. Acharya and Gonzales (2014) also found that migration from poor households in Nepal resulted in an increase of investment in children's education and higher child educational enrolment. Financial resources, such as from remittances, are therefore important, particularly for the children whose education is not subsidised by the state. In the context of limited public educational support, $\mathrm{Lu}$ (2014) also argued that additional resources from migrant 
parent's remittances which are directed to educational spending improve children's access to education. Other studies also demonstrated that remittances reduce the economic pressure on children to leave school and undertake work that contributes to the household's financial resources (McKeinzie, 2005; Brown \& Poirine, 2005), improve left-behind children's wellbeing in terms of access to material goods and educationrelated services (Semyonov \& Gorodzeisky, 2008), and offset poor educational performance $(\mathrm{Hu}, 2013)$. However, remittances may also have the contrary effect by creating disincentives for children to continue their education and instead motivating them to migrate for employment while their migration opportunities seem greater, as observed by de Brauw and Giles (2006) in China, and Kandel and Massey (2002) in Mexico.

Second, reflecting on the context of high levels of public educational provision, on the other hand, the family's economic resources from parent's remittances may have limited impact. Public educational provision can evidently lower the direct cost of schooling and in turn reduce the importance of family economic resources (Post \& Post, 1998; Aughinbaugh \& Gittleman, 2003). To capture the context of public education support, our study looks at our two child age-cohorts separately. Thus our second hypothesis expects that the family's financial resources (including from remittances) are important only for the older children as the younger children receive public education support (free education). The presence of parents can be more crucial than parent's remittances to motivate the children to stay in school, given the fact that younger children tend to be more responsive to their parents' aspirations. This was highlighted by Hanson and Woodruff (2003) and McKenzie (2005), who argued that parental migration can be detrimental to children's education in term of the lack of proper guidance, supervision and motivation for children to remain in school. We also expect mothers - both co- 
resident mothers and migrant mothers - who are commonly associated with emotional connectedness to their children (Parreñas, 2008) to be better motivators for their children to remain in school than fathers.

Our third hypothesis is based on the expectation that material benefits from parental migration are important for the educational enrolment of older children as their education involves costs, and typically considerable costs, to the family. Households will also undoubtedly view remittances as part of their financial resources when thinking about whether they can afford to pay for non-compulsory education. We therefore expect remittances, along with other household income, to be positively related to school enrolment for older children.

\section{Mixed-method research design}

We examine the impact of parental migration on children's education using the complementary strength of quantitative and qualitative methods of analysis. We first analyse quantitative data collected from a household survey to identify the determinants of children's educational enrolment, and then triangulate the analysis with in-depth interviews conducted with a sub-sample of households.

Data are drawn from the Migrating-out of Poverty (MOOP) household survey conducted in 2013 and selected follow-up in-depth interviews with parents and children between 2015 and 2016. The survey and interviews focused on households in rural Ponorogo in Indonesia, an area known for its high levels of labour migration. Using a quota sampling strategy, the survey was completed for approximately 1,200 households from 12 villages in the Sampung sub-districts, with the household head as the main respondent. We purposively targeted approximately 300 households for each household category (internal migrant, international migrant, return migrant and non-migrant), with 
a balance in terms of the gender of the main respondent. The overarching definition of a migrant included anyone who used to live in the household and has left the area in the past 10 years, with a duration of (intended) absence of at least 3 months (definition adapted from Bilsborrow, Oberai, \& Standing, 1984). Internal migration refers to work destinations within Indonesia but outside of Ponorogo, while international migration refers to destinations outside Indonesia. Adapted from Carletto and de Brauw (2008), a return migrant is defined as anyone who has ever lived elsewhere for 3 months or more over the past 10 years but has already returned and lived in the household for at least the 12 consecutive months prior to survey.

The information on children and their parents is sourced from the household roster section of the questionnaire that listed particulars of the household members. If members migrated outside the area permanently, they are not recorded in the roster or included in the sample. However, if they undertook temporary migration, for example migrating alone either for work or for education, they are recorded in the roster. As the survey is not specifically focused on the children, it should be noted that children living in the migrant households do not necessarily have parents who are migrant. The migrant(s) can be other household members or the children themselves who used to live in the household prior to migration. Our sample of children is selected based on the age of household members aged between 7 to 21 years. As there can be more than one child in a household, our models account for the clustering of standard errors at the household level to allow for arbitrary correlation in the error structure of individuals within a household.

The information on parental migration status is based on whether the child's mother or father is currently undertaking either internal or international migration, and whether the parent(s) is/are currently migrant, return migrant or non-migrant. As there are very few children with two migrant parents in the survey, we dropped these cases for 
the analysis to avoid possible estimation bias.

In this initial analysis, we employ multivariate logistic regression models to investigate the association between parental migration and children's education. The outcome is a dummy variable denoting children who are enrolled in education, and our main predictors are parental migration status and child age-cohort. For parental migration status, we code 0 for the reference group of non-migrant parents, 1 for paternal migration, 2 for maternal migration and 3 for return migrant parent. The child age-cohort is divided into two categories: 1 for children age $7-15$ years (younger cohort, equivalent to those in lower secondary or below who are eligible for free education), and 0 for children age 16-21 years (older cohort, equivalent to those in upper secondary level and above who are not eligible for free education ${ }^{3}$ ).

We also include variables capturing the characteristics of children and their households in our statistical models that are common confounders of the main associations of interest, based on the particular context of the study. These include a dummy variables for child gender (female $=1$ ), having younger siblings, and having older siblings, as well as household income including remittances ${ }^{4}(1=$ low - bottom quintile; 2=medium - middle two quintiles; $3=$ high - top two quintiles), household's perception of quality of life compared to five years ago ( 1 =better; $2=$ same or neutral; $3=$ worse $)$, number of adults in the household (continuous variable), number of children aged below 18 years in the household (continuous variable), and household head's educational attainment (1=upper secondary \& above), gender ( $1=$ female) and age (continuous variable). The regression analyses are conducted, firstly, for the combined sample of children in both age cohorts, and then separately for the younger cohort and older cohort. The latter aims to examine whether impacts of parental migration vary across different cohorts, 
considering the fact that the older child cohort most needs their parent's financial support to continue their education, while the younger child cohort might need their parent's socio-emotional support more than the parent's financial support. Separating the models allow us to investigate if the impacts of other key variables vary between younger children and older children.

To aid the interpretation of the model findings we also incorporate qualitative data from interviews. We conducted in-depth interviews with 24 pairs of adults and children aged 15-24 years, selected from households with different migration statuses (nonmigrant, current migrant, return migrant). The large majority of the child respondents are from our older child cohort. The interviews aimed at gathering deeper insights into the household's strategies with regard to migration and livelihood plans, remittance use and aspirations. More specifically for this paper, we explore the narratives the children construct about their responses to parental absence.

\section{Rural Ponorogo in context}

Ponorogo, the study site, is a regency in East Java well-known for its large numbers of transnational labour migrants. It has consistently maintained its position as one of Indonesia's top regencies in term of overseas migration numbers, where over 10,000 people (approximately 2 per cent of its working-age population between 15 and 65 years) left every year to work overseas in the 2011-2014 period (BNP2TKI, 2014) and many more migrated to work in other provinces and cities within Indonesia. The majority of the population (63 per cent) in the Sampung sub-district of Ponorogo, where the study took place, depended on agriculture for their main livelihood (BPS Kabupaten Ponorogo, 2015). The heavy reliance on agrarian incomes means that people's incomes are seasonal and susceptible to shocks such as fluctuations in commodity prices, inflation 
and weather conditions. According to our survey, most migrants are involved in casual jobs (16.0 per cent), unpaid jobs (32.4 per cent) or were unemployed (12.9 per cent) prior to migration due to limited paid jobs available in the area. Migration, therefore, was seen as a way of securing economic resources for the household's immediate needs and also for its longer term aspirations.

Only one third of all migrants in our survey allocated remittances specifically for education purposes, although approximately half of the migrants with children did so. This relatively low proportion may be related to government support for public education. Under the Law on National Education (No.20/2003) and the Constitution Amendment III (PP 47/2008), all Indonesian citizens are guaranteed the right to basic education, defined as six years of primary school and three years of lower secondary school. Consequently, the government has an obligation to support basic education without charging fees, although in reality it is common that parents still have to make additional school-related payments, i.e. for admission, and extracurricular and fieldtrip activities (Jakarta Globe, 2011). A school operational assistance scheme (Bantuan Operasional Sekolah-BOS) was also implemented in 2005 as a way of allocating funds directly to schools with the aim of keeping children in school (World Bank, 2014). By 2008, the Indonesian state met its target of allocating at least 20 per cent of the state budget for national education, which allowed for the improvement of basic education resources and also for the programme to be expanded throughout Indonesia (Suryadarma \& Jones, 2013). In our field-sites, primary and lower secondary children in public schools have been receiving nearly full educational support, including school fee waivers, as well as free uniforms and books. As for upper secondary school children, only those from households with incomes per capita falling below the poverty line and attending public schools, can receive public education support. The need for parental support of educational expenses is much more pronounced 
for these children.

\section{Children of migrant fathers and migrant mothers}

The descriptive statistics (Table 1) show that of the 1,031 children aged 7-21 years, more than 40 per cent have at least one parent who has ever migrated for work outside the area. Our sample shows that the incidence of maternal migration (15.6 per cent) is greater than that of paternal migration (10.1 per cent). This is in line with the feminisation of migration in Indonesia, where there is a highly gendered demand for women workers both within Indonesia for domestic work, service work, factories and shopping malls (Elmhirst, 2007) as well as at overseas destinations with job opportunities in care and domestic work (Khoo \& Yeoh, 2017). The migration process also makes it easier for women to access overseas migration opportunities compared to men, as the former rarely need to raise upfront payments to facilitate migration (Platt, Baey, Yeoh, Khoo \& Lam, 2017).

A greater proportion of paternal migration is found among the children from the younger cohort (76.0 per cent) compared with the older cohort (24.0 per cent). This supports Asis's (2006) observation on traditional gender role preferences for father's breadwinning through migration for work and mothers staying at home to care for younger children until they are more emotionally mature and able to be independent. Because younger children benefit from free education under the compulsory basic education policy, the younger children of migrant (and non-migrant) fathers are also more likely to be in education. In addition, the descriptive statistics show that a greater proportion of children of migrant fathers ( 79.8 per cent) are receiving remittances specifically allocated for children's education, compared with children of migrant mothers (62.1 per cent). It should be noted that other family members, such as the 
children's older siblings, or grandparent(s) or even other relatives (aunts/uncles) may also support the children's education by sending educational remittances. This is reflected in the 15.6 per cent of children of non-migrant parents and 5.9 per cent of children of return migrant parents whose households are receiving educational remittances.

\section{[Insert Table 1 here]}

Over one-third of children who are not in education have migrated for work, and three children are migrant while attending part-time education. All migrant children in our sample are from the older cohort (aged 16-21). They undertake unaccompanied migration for work outside the area, predominantly to internal destinations where the minimum age requirement to be eligible for work is more flexible than that at international destinations. International destination countries typically stipulate a legal minimum age of 18 years for international migrants and between $21-23$ years specifically for those migrating as overseas domestic workers (Khoo \& Yeoh, 2017). The descriptive statistics also reveal that a greater proportion of migrant children are from households with a migrant mother (6.8 per cent) and non-migrant parents (18.8 per cent), while none are from households with a migrant father or return migrant parent(s).

\section{Paternal migration, maternal migration and children's educational enrolment}

The results of our logistic regression analysis (Table 2) show that children of migrant fathers are nearly two and a half times more likely, and children of return migrant parents nearly twice as likely to enrol in school compared with children of non-migrant parents $(\mathrm{OR}=2.49, p<0.01$ and $\mathrm{OR}=1.99, p<0.01$ respectively). On the other hand, the school enrolment of children of migrant mothers does not differ significantly from that of children of non-migrant parents. The family's financial resources from remittances 
and/or other income are generally important for improving children's educational access. Our results show that those from households in the lowest income quintile have lower school enrolment compared with those from high income households, although the association is only marginally significant. Along with the evidence of a higher proportion of children of migrant fathers receiving remittances allocated specifically for education purposes (see Table 1), our analysis suggests that the greater likelihood of school enrolment among children of migrant fathers is influenced by the remittances received by most of these children. Thus remittances can be the pathway to increased educational enrolment.

\section{[Insert Table 2 here]}

The prevailing gendered views in rural Indonesian society, with social expectations that fathers adhere to the prescriptive role as provider for the children and mothers as carer and nurturer, may also contribute to the more positive impact of paternal migration than maternal migration on children's education. Unlike maternal migration, paternal migration is commonly observed to be less likely to change children's everyday care and life as the left-behind mother is likely to be their main caregiver. Therefore, paternal migration is less likely to influence children's emotional wellbeing, and hence their motivation to remain in school. Our interview with fifteen-year-old Valentina reflects the prevailing sentiment. Valentina related how when she was younger she had wanted her father to be home, but now she realised the importance of her father's migration, which has become a source of encouragement to her to keep persevering in her studies. Her father's migration has enabled her to study in her 'dream school' (vocational nursing school) despite exorbitant school fees. Valentina described herself as a 'lucky child' as she (and her brother) received care from her mother, and also sufficient financial support from her migrant father's remittances. In this vein, she also shared her 
views - based on observing her friend's situation - that mother's migration tended to be more problematic than father's migration. Echoing those of other left-behind children, her views adhered to the well-accepted script of the gender division of household labour:

'When the mother migrates, the father is usually busy working [outside the household/in the farm]. But if father migrates, the mother is often not working [outside the household]. I think mother's migration can cause some issues... Father does not usually give enough attention to the children [compared to mothers who do]. This is similar to my friend's case. My friend developed deviant behaviour skipped school and playing around. He was almost expelled from the school, but then his mother returned home immediately to take care of him, and finally he was able to continue school and [eventually] graduated from secondary school.'

Family composition, particularly the existence of siblings, matters. Our result shows that those with younger sibling(s) are less likely to enrol in education $(\mathrm{OR}=0.58$, $p<0.01)$, while those with older sibling(s) are more likely to enrol in education (OR = 1.47, $p<0.01$ ). Our qualitative interview findings provide some confirmation that educational outcomes are influenced by sibling considerations. Older siblings, particularly those from low income households, are seen to prioritise their younger siblings' education above their own. Seventeen-year-old Amalina told us that her older sister decided not to pursue her own upper secondary education, as she wanted to let Amalina and her other younger siblings stay in education while also contributing to shoring up the household's economic resources:

'My older sister's highest education level is SMP (lower secondary school) [...] although she was actually interested to continue her study but she said that she did not want to add burden to the family. She said to my father that she wanted to let me study to the higher level instead. She wanted to help pay for our education expenses. Indeed, she has provided a substantial amount of money for us when we really need it [...] She went to Surabaya to work after she graduated from SMP and worked in a restaurant. After that, she joined my mother working as a domestic worker.' 
While living in a household with limited economic resources with many dependents to support, Amalina's sister felt a strong sense of obligation to reduce the burden of her parents. Stopping her education and taking on paid jobs or migrating for work were seen as ways to demonstrate her responsibility for family betterment in the future.

\section{Child age-cohort, free education and school enrolment}

Our analytical sample shows that approximately 89.5 per cent of children aged 715 years are enrolled in school. This may be attributed to the effect of Indonesia's compulsory nine-year education. On the other hand, among children aged 16-21 years (older cohort), fewer than half (41.1 per cent) are enrolled in education. Their lower educational enrolment may largely be attributed to the fact that their educational costs are much more expensive as they are not covered under the compulsory education policy. In most cases, the parents evidently need to shoulder their children's educational expenses. The results of our logistic regression analysis (Table 2) confirm the descriptive findings, indicating that older children have lower school enrolment even after accounting for possible confounding factors.

\section{[Insert Table 3 here]}

The separate models for children from two different age-cohort that distinguish the eligibility for free education support (Table 3) indicate that parental migration has different impacts for younger children and older children. For the younger cohort, parental migration appears to have a negative impact on their educational outcome. Despite receiving free public education support, younger children of migrant mothers or return migrant parents have significantly lower educational enrolment than those of nonmigrant parents $(\mathrm{OR}=0.38, p<0.01$ and $\mathrm{OR}=0.45, p<0.01$ respectively $)$. On the other hand, the adverse impact of paternal migration is not statistically significant. Our 
measurement of educational outcome is based on the age of the children and does not include their education pace (i.e. whether they are relatively young or old to be at a particular education level). It could be that the negative impact of maternal migration is driven by some children of migrant mothers having a faster pace, i.e. being younger than 16 when they complete compulsory education and leave school. However, this is unlikely to be the explanation as our sample indicates that lower educational enrolment is found at all ages of the younger children of mother migrants. Hence, it seems that the presence of mothers, who are commonly associated with emotional connectedness to their children (Parreñas, 2008), is important for the younger children. This coheres with prevailing gender expectations in Indonesian society prescribing mothers as responsible for child care and nurturing, especially for younger children who are generally thought to be less mature and less able to handle the emotional aspect of parental absence than older children. A similar result is seen for younger children with return migrant parent(s). Their educational enrolment is lower compared with those with non-migrant parents. This is consistent with our other findings as our survey shows that a greater proportion of return migrant parents (65 per cent) are return migrant mothers. It seems that the adverse impact on children's education is mostly found for those children who were ever left-behind by a migrant parent, particularly by their mother during their early life.

Our qualitative data, despite being mostly from interviews with the older age cohort, do suggest that parental presence and guidance are important factors in encouraging and motivating younger children to remain in education. Twenty-year-old Mulya, for example, shared a story about his decision, at a relative young age of 13 years, not to continue his schooling. This was a few years after his mother left to work in Sulawesi, while his father was also migrating back and forth to Kalimantan to work in order to sustain the family's livelihood. Ever since then, his mother had not contacted 
him or returned home. Feeling upset, the young Mulya decided to drop out of school when he was still in lower secondary, without consulting his parents. When his father returned home, Mulya had already been out of school for several months. Mulya recalled the reasons he gave his father:

I can't get along with my friends at school. I was bored in school and thought I want to work to change my destiny. Grandfather also said that it's up to me whether to continue school or not, as in the end I have to live my life myself.

Feeling disappointed that he had not been able to give adequate attention to his children when he was away, Mulya's father decided to remain at home. At this point, Mulya intended to return to school, but the financial situation did not permit him to do so, particularly when circumstances worsened with the hospitalisation of his father who came down with dengue fever and needed much money for medical care. Mulya then abandoned plans to return to school, and decided to work in a local furniture shop to reduce the family's financial burden. Mulya case shows the complexities of children's experience of parental migration in relation to their access to education. Despite the opportunity to receive free basic educational support, young Mulya was in the end unable to continue his education. Lack of parental attention during his mother's migration, in tandem with family poverty and illness, offset the possible benefits of public education support.

In contrast, our results reveal a rather different picture for the older age cohort, one where parental migration has a positive impact on school enrolment. This suggests that remittances from migrant parents may be important and serve as additional financial resources that allow older children to access education beyond compulsory schooling. In addition, socio-economic inequality is evident among older children as our results indicate that those from low income households are significantly less likely than those from high income households to be enrolled in school $(\mathrm{OR}=0.61, p<0.05)$. For older 
children in households above the lowest income quintile, the material benefits of parental migration seem to offset the socio-emotional costs of parental absence. Despite feeling sad about the absence of their parents during migration, a number of older children interviewed told us that they were able to understand the reasons for their parents' absence, and accepted their absence with a level of emotional maturity. They also found ways to develop resilience in the face of the emotional costs of separation. For example, one interviewee, seventeen-year-old Lestari, spoke about how she appreciated the sacrifice her mother made in migrating to earn money to support Lestari's education, which '... would otherwise be unattainable'. She narrated how she took full advantage of her mother's remittances to pursue her own educational endeavours:

'Mother's migration has influenced my way of thinking [...] although it is sad that she has to be away and working hard for us. As her daughter, I should appreciate her by studying well [...] (I believe) my mother can definitely help to realise my dream to get a better job in the future. In the end, I want to make my mother proud of me.'

We find also that the positive impact of paternal migration on the older children is even greater than that of maternal migration. Older children of migrant fathers are nearly six times more likely to be enrolled in school compared with children of nonmigrant parents $(\mathrm{OR}=5.91, p<0.001)$. Given that the impact of remittances is accounted for within household income, it seems that any residual effect of parental migration must work through an alternative non-financial pathway. This could include the motivation to continue in education resulting from explicit encouragement from parents. Thus, the lesser positive impact of maternal migration compared with paternal migration may possibly be explained by the reduced influence of migrant mothers when they are away. Some migrant mothers, particularly those who are domestic workers working abroad, may face challenges making contact with their children if they have little free time or few spare resources to spend on mobile phones. Our qualitative interviews reveal other 
factors, such as emotional loss, which seems more likely to be displayed by children of migrant mothers than by children of migrant fathers, and which may be related to traditional gender roles. It is common, and indeed expected, that fathers undertake migration to provide for the family. Feelings about migrant mothers are more conflicted. Some older children of migrant mothers in our interviews expressed feelings of pity towards their mother for having to work overseas for so long for the sake of their wellbeing and education; their hope was that their mothers would soon be able to return for good. Eighteen year old Eti, for example, showed a strong sense of obligation to her migrant mother and positioned herself as a responsible and dutiful daughter who wanted to take on paid work instead of continuing in education in order to reduce her mother's burdens and let her return home:

'There was a time when my mother insisted that I continue my education to university and she wanted to keep working in overseas to support it. I refused. I wanted to find a job. I thought it'd be better if I didn't trouble my parents. I pity them if I have to keep asking money until I am grown up. The university fees here are very expensive, not like primary or secondary school.'

Postponing further education or leaving education and entering paid employment are commonly seen as ways for young people to repay their migrant mothers for the sacrifices they have made by being away from the family for extended periods. In fact, some interviewees also expressed a desire to replace their mothers in accessing labour migration as a livelihood option. Interestingly, this is especially so among children of migrant mothers (see Somaiah, Yeoh \& Arlini (forthcoming) on young Indonesian women who choose to stay). A closer look at the descriptive statistics for our sample confirmed that it is only the older children of migrant mothers, and not the children of migrant fathers, who were undertaking migration for work at the time of interview. This further provides additional evidence that paternal and maternal migration are viewed somewhat differently by the children left-behind and that the impact of parental migration 
on children's school enrolment extends beyond the role of enhanced material resources from remittances.

\section{Conclusion}

In recent years, overall access to education has continued to increase in Indonesia, in part due to progress in public education reforms, including the increase in public educational spending and support to ensure basic nine-year compulsory education for all. Despite this, educational equity is far from complete, as access to education for children from poor households, especially beyond lower secondary school, is still low. Our study offers new insights into Indonesian children's education enrolment in the context of parental migration, investment in improving public educational infrastructure and prevailing gender-normative roles with regard to childcare and migration. We find that, in general, parental migration has a positive influence on children's educational enrolment, although this varies by the age-cohort of the child and the gender of the migrant parent. For children of migrant mothers, the influence is only positive for older children who do not have access to free education. The family's financial resources, from remittances and other household income, are crucial to improving children's educational access beyond compulsory education. For younger children, paternal migration makes no difference to school enrolment, while maternal migration and return migration have significant negative effects, reducing the likelihood of being in school. When mothers migrate, children's motivation to remain in education appears to be negatively affected, possibly as a result of gender-normative expectations around the performance of carework. Particularly for the younger children in our study, the need for maternal presence to provide everyday gendered care appears to feature more prominently than the need for material support from parental remittances in a context where the financial costs 
of their education are covered under the public education policy.

Despite the increasing feminisation of labour migration, the traditional gender division of labour prescribing mothers as the most appropriate nurturers of children appears to persist. We also observed a greater preference among children for paternal migration over maternal migration, as summed up by one interviewee who considered herself 'lucky' to be receiving material support for her education from her migrant father while also receiving care and emotional support from her left-behind mother. In these circumstances, her motivation to continue her education and give something back to her parents in the future was high. Further, the mixed findings for children of mother migrants show that age matters. Some older children expressed appreciation to their migrant mothers for making it possible for them to achieve their dreams, but others felt a sense of dismay and sadness when they think about their migrant mothers' sacrifice. In some cases, yearning for their mothers' return may also lead to a desire - linked to a growing sense of responsibility as they approach young adulthood - to replace their mothers' earnings by deciding to forego or postpone further education in order to take on paid work.

Although we have been able to establish various associations between parental migration and school enrolment and interpret these through the eyes of children themselves, the study has a number of limitations. First, the study is limited in geographical scope; it provides a case study of a rural area which is experiencing high out-migration rates, and its findings may not be generalisable to children across different rural (or urban) settings in Indonesia. Second, it focuses specifically on school enrolment and does not explore children's conduct or academic achievements in schools as the survey does not include data on these aspects of education. Third, the cross-sectional nature of the survey data means that causal direction remains unclear. It could be, for 
example, that fathers whose children are not doing well in school (and hence are at greater risk of leaving education) are less likely to migrate. Further research requires longitudinal data to clarify the mechanisms underlying the associations observed. Despite these limitations, the study offers some important findings by suggesting the differential influences of paternal and maternal migration on access to education for children of different ages. It is also able to throw some light on the motivations of children to stay or leave schooling through its use of a mixed-methods approach.

Our findings imply that parental migration has the potential to improve children's educational outcomes, despite the less than optimal impact for children of migrant mothers. With the increasing feminisation of labour migration within and from Indonesia, this study provides evidence suggesting that policies could be developed to support migrant mothers in contributing to the wellbeing of their family and children. Ideally, such policies should be directed to mitigating the negative impact of maternal migration on school enrolment among younger children, as well as improving the positive impact on older children's education. This might involve facilitating communication between migrant mothers and their left-behind children over the distance, for example. With a more positive impact of maternal migration, society may gradually support and appreciate the mother's productive role beyond their traditional socio-reproductive responsibilities. Rapid development of information and communication technology (ICT) can contribute to bridging the gap in their relationships and communication, but, challenges remain as the basic right of many low-skilled female migrants, especially domestic workers, to have the freedom to communicate with their family is still limited. For example, many Indonesian migrant mothers are domestic workers in the Middle East where the conditions of employment make it difficult for them to contact their children and thus are unable to 'mother from afar', which may explain the negative association between 
maternal migration and younger children's school enrolment. Moreover, fathers could be encouraged to provide their younger children with higher quality care and greater emotional support. There is also a need for more research directed at addressing other related issues and challenges beyond school enrolment for children growing up in the long-term absence of migrant parent(s). This will provide a stronger foundation for assessing and advocating for different kinds of support - financial, social and emotional - that can be provided by family, kin, community and the state to growing numbers of left-behind children in the rural areas of developing economies in Southeast Asia.

\section{Acknowledgements}

This work has been funded by UK aid from the UK government through the Migrating out of Poverty (MOOP) Research Programme Consortium; however the views expressed do not necessarily reflect the UK government's official policies.

\section{Notes}

\footnotetext{
${ }^{1}$ Both studies on Indonesia (Lu 2014; Nguyen \& Purnamasari, 2011) focused on children age 618 years and did not distinguish their age-cohort, making it difficult to know which group of children potentially received relevant public education benefits. They also used data collected before the nine-year compulsory education policy was implemented.

${ }^{2}$ Only Myanmar has a free education policy for five years.

${ }^{3}$ However, scholarships may be awarded in exceptional circumstances.

${ }^{4}$ The measurement of income includes remittances that are not limited to those sent by migrant parents but include any sent by other household members or even other people/relatives outside the household. The multicollinearity test indicates that there is no correlation between household income inclusive of remittances and parental migration status in our empirical data. In fact, accounting for remittances within household income allows us to argue that any residual parental migration effect works through an alternative non-financial pathway, such as socioemotional support or motivating the child.
} 


\section{References}

Acharya, C. P., \& Gonzalez, R. L. (2014). How do migration and remittances affect human capita investment? The effect of relaxing information and liquidity constraints. Journal of Development Studies, 50(3), 444-460. doi:10.1080/00220388.2013.866224

Al-Samarrai, S., \& Cerdan-Infantes, P. (2013). Where did all the money go? Financing basic education in Indonesia. In D. Suryadarma \& G. Jones (Eds.), Education in Indonesia (pp. 109-138). Singapore: ISEAS-Yusof Ishak Institute.

Arguillas, M. J. B., \& Williams, L. (2010). The impact of parents' overseas employment on educational outcomes of Filipino children. International Migration Review, 44(2), 300-319. doi:10.1111/j.1747-7379.2010.00807.x

Asis, M. M. B. (2006). Living with migration: Experiences of left-behind children in the Philippines. Asian Population Studies, 2(1), 45-67. doi:10.1080/17441730600700556

Asis, M. M. B., \& Ruiz-Marave, C. (2013). Leaving a legacy: Parental migration and school outcomes among young children in the Philippines. Asian and Pacific Migration Journal, 22(3), 349-375. doi:10.1177/011719681302200303

Aughinbaugh, A., \& Gittleman, M. (2003). Does money matter? A comparison of the effect of income on child development in the United States and Great Britain. Journal of Human Resources, 38(2), 416-440. doi:10.2307/1558750

Bilsborrow, R. E., Oberai, A. S., \& Standing, G. (1984). Migration surveys in low income countries: guidelines for survey and questionnaire design. London: Croom Helm

BNP2TKI (2014). Data of the placement and Protection on the Indonesian Overseas Migrant Workers. Retrieved from http://www.bnp2tki.go.id/uploads/data/data 22-062015022721 Data P2TKI Tahun 2013.pdf

BPS Kabupaten Ponorogo (2015). Statistik Daerah Kecamatan Sampung 2015. Retrieved from http://ponorogokab.bps.go.id/website/pdf_publikasi/Statistik-DaerahKecamatan-Sampung-2015.pdf

Brown, R. P., \& Poirine, B. (2005). A model of migrants' remittances with human capital investment and intrafamilial transfers. International Migration Review, 39(2), 407-438. doi:10.1111/j.1747-7379.2005.tb00272.x

Carletto, C. and de Brauw, A. (2008) Measuring Migration Using Household Surveys. Washington D.C.: The World Bank Migration Operational Vehicle, Operational Note No. 2. 
Cortes, P. (2015). The feminization of international migration and its effects on the children left behind: Evidence from the Philippines. World Development, 65, 6278. doi:10.1016/j.worlddev.2013.10.021

Creighton, M. J., Park, H., \& Teruel, G. M. (2009). The role of migration and single motherhood in upper secondary education in Mexico. Journal of Marriage and Family, 71(5), 1325-1339. doi:10.1111/j.1741-3737.2009.00671.x

de Brauw, A., \& Giles, J. (2016). Migrant opportunity and the educational attainment of youth in rural China. Journal of Human Resources, 52(1), 272-311. doi:10.3368/jhr.52.1.0813-5900R

Dreby, J., \& Stutz, L. (2012). Making something of the sacrifice: gender, migration and Mexican children's educational aspirations. Global Networks, 12(1), 71-90. doi: 10.1111/j.1471-0374.2011.00337.x

Elmhirst, R. (2007). Tigers and gangsters: Masculinities and feminised migration in Indonesia. Population, Space and Place, 13(3), 225-238. doi:10.1002/psp.435

Hanson, G. H., \& Woodruff, C. (2003). Emigration and educational attainment in Mexico. Mimeo, University of California San Diego.

Hoang, L. A., Lam, T., Yeoh, B. S. A. \& Graham, E. (2015). Transnational migration, changing care arrangements and left-behind children's responses in South-east Asia. Children's Geographies, 13(3), 263-277. doi:10.1080/14733285.2015.972653

Hu, F. (2013). Does migration benefit the schooling of children left behind? Evidence from rural northwest China. Demographic Research, 29(2), 33-70. doi: 10.4054/DemRes.2013.29.2

Jakarta Globe. (2011, June 11). Is this the final bell for school fees in Indonesia? Retrived from http://jakartaglobe.id/archive/is-this-the-final-bell-for-school-fees-inindonesia/

Jampaklay, A. (2006). Parental absence and children's school enrolment. Asian Population Studies, 2(1), 93-110. doi:10.1080/17441730600700598

Jordan, L.P., \& Graham, E. (2012). Resilience and well-being among children of migrant parents in South-East Asia. Child Development, 83(5), 1672-1688. doi:10.1111/j.1467-8624.2012.01810.x

Kandel, W., \& Massey, D. S. (2002). The culture of Mexican migration: A theoretical and empirical analysis. Social Forces, 80(3), 981-1004. doi:10.1353/sof.2002.0009

Khoo, C. Y., \& Yeoh, B. S. A. (2017). Responsible adults-in-the-making: Intergenerational impact of parental migration on Indonesian young women's 
aspirational capacity. $\quad$ Geoforum, $\quad 85, \quad 280-289$.

doi:10.1016/j.geoforum.2017.08.005

Khoo, C. Y., Platt, M., \& Yeoh, B. S. A. (2017). Who migrates? Tracking gendered access to migration within households "in flux" across time. Journal of Immigrant \& Refugee Studies, 15(3), 326-343. doi:10.1080/15562948.2017.1283456

Lam, T. \& Yeoh B. S. A. (2014). Long-distance fathers, left-behind fathers and returnee fathers: Changing fathering practices in Indonesia and the Philippines. In M. Inhorn, W. Chavkin \& J.A. Navarro (Eds.), Globalized Fatherhoods: Emergent Forms and Possibilities in the New Millennium (pp. 103-128). New York: Berghahn.

Lam, T., \& Yeoh, B. S. A. (2016). Migrant mothers, left-behind fathers: The negotiation of gender subjectivities in Indonesia and the Philippines. Gender, Place \& Culture, 25(1), 1-14. doi:10.1080/0966369X.2016.1249349

Lu, Y. (2014). Parental migration and education of left-behind children: A comparison of two settings. Journal of Marriage and Family, 76(5), 1082-1098. doi:10.1111/jomf.12139

Manning, C., \& Pratomo, D. S. (2013). Do migrants get stuck in the informal sector? Findings from a household survey in four Indonesian cities. Bulletin of Indonesian Economic Studies, 49(2), 167-192. doi:10.1080/00074918.2013.772940

McKenzie, D. J. (2005). Beyond remittances: The effects of migration on Mexican households. In C. Özden \& M. Schiff (Eds.), International Migration, Remittances and the Brain Drain (pp. 123-147). Washington, DC: World Bank.

McKenzie, D., \& Rapoport, H. (2011). Can migration reduce educational attainment? Evidence from Mexico. Journal of Population Economics, 24(4), 1331-1358. doi:10.1007/s00148-010-0316-X

Nguyen, L. Yeoh, B. S. A. \& Toyota, M. (2006). Migration and the well-being of the 'left-behind' in Asia. Asian Population Studies, 2(1), 37-44. doi: $10.1080 / 17441730600700507$

Nguyen, T., \& Purnamasari, R. (2011). Impacts of international migration and remittances on child outcomes and labor supply in Indonesia: How does gender matter? World Bank Policy Research Working Paper No. 5591. doi:10.1596/1813-9450-5591

Parinduri, R. A., \& Thangavelu, S. M. (2011). Impact of remittances on human capital development of children in Indonesian household. Retrived from https://www.nottingham.ac.uk/gep/documents/conferences/2011/malyasia-confjanuary/shandre-thangavelu.pdf

Parreñas, R. S. (2001). Mothering from a distance: Emotions, gender, and intergenerational relations in Filipino transnational families. Feminist studies, 27(2), 361-390. doi:10.2307/3178765 
Parreñas, R. S. (2008). Transnational fathering: Gendered conflicts, distant disciplining and emotional gaps. Journal of Ethnic and Migration Studies, 34(7), 1057-1072. doi:10.1080/13691830802230356

Platt, M., Baey G., Yeoh, B. S. A., Khoo C. Y. \& Lam T. (2017). Debt, precarity and gender: male and female temporary labour migrants in Singapore. Journal of Ethnic and Migration Studies, 43(1), 119136. doi: 10.1080/1369183X.2016.1218756

Post, D., \& Pong, S. L. (1998). The waning effect of sibship composition on school attainment in Hong Kong. Comparative Education Review, 42(2), 99-117. doi:10.1086/447491

Rahman M. M., \& Lian K. F. (2009). Gender and the remittance process: Indonesian domestic workers in Hong Kong, Singapore and Malaysia. Asian Population Studies, 5(2), 103-125. doi:10.1080/17441730902992059

Semyonov, M., \& Gorodzeisky, A. (2008). Labor migration, remittances and economic well-being of households in the Philippines. Population Research and Policy Review, 27(5), 619-637. doi:10.1007/s11113-008-9084-7

Somaiah, B. C., Yeoh, B. S. A., \& Arlini, S. A. (forthcoming) 'Cukup for me to be successful in this country': 'staying' among left-behind young women in Indonesia's migrant-sending villages. Global Networks.

Suharti. (2013). Trends in education in Indonesia. In D. Suryadarma \& G. W. Jones (Eds.), Education in Indonesia (pp. 15-52). Singapore: ISEAS-Yusof Ishak Institute.

Suryadarma, D., \& Jones, G. (Eds.). (2013). Education in Indonesia. Singapore: ISEASYusof Ishak Institute

UNESCO (2017). Situation analysis of out of school children in nine Southeast Asian countries. Retrieved from http://unesdoc.unesco.org/images/0025/002527/252749e.pdf

World Bank. (2014). World Bank and education in Indonesia. Retrieved from http://www.worldbank.org/en/country/indonesia/brief/world-bank-andeducation-in-indonesia.

Zimmer, Z. \& Van Natta, M. (2018). Migration and left-behind parents and children of migrants in Cambodia: a look at household composition and the economic situation. Asian Population Studies, 14(3), 271-289.

doi: 10.1080/17441730.2018.1513111 
Table 1. Descriptive Statistics of the Sample

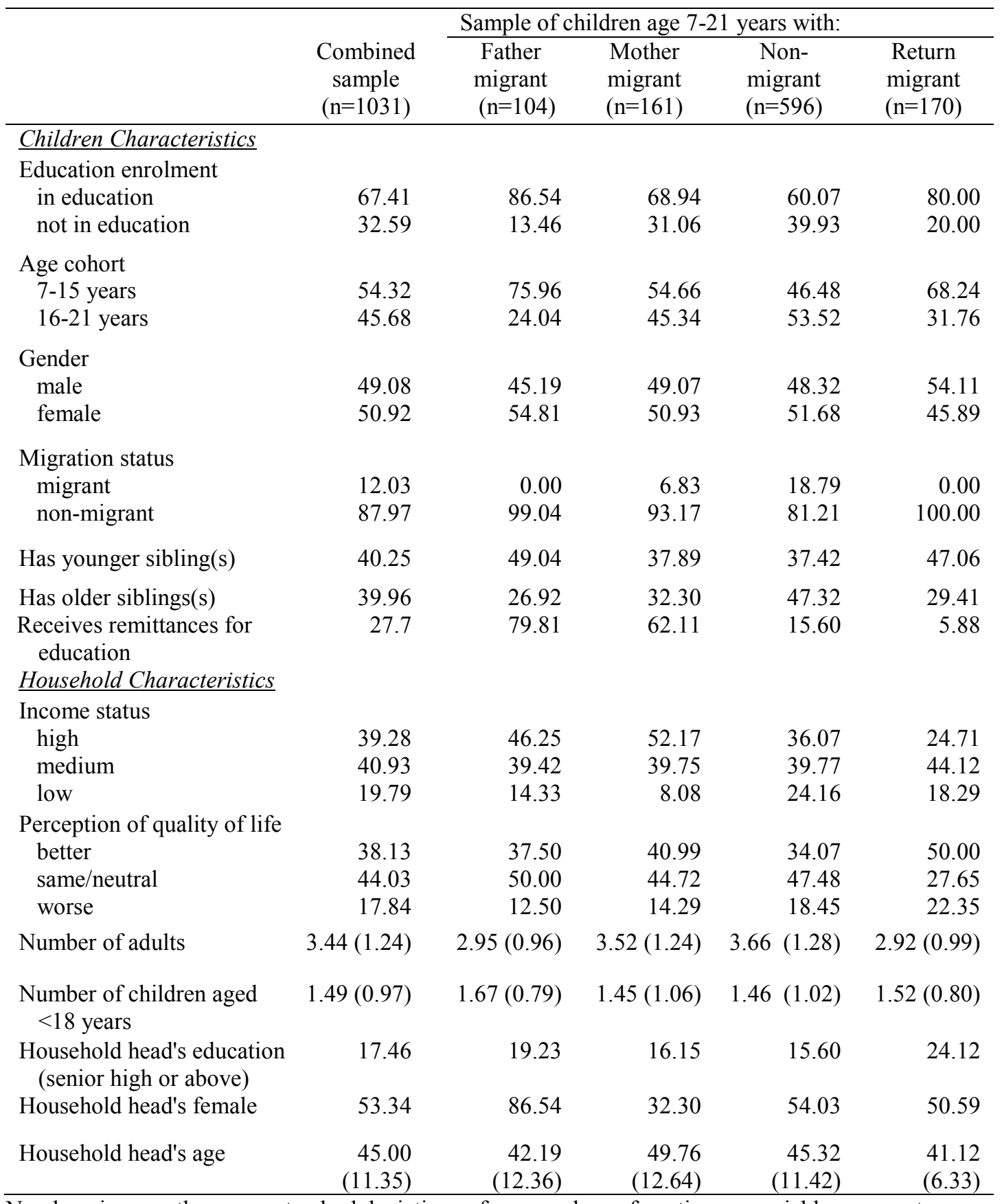

Numbers in parentheses are standard deviations of mean values of continuous variables; percentages are shown for categorical variables. 
Table 2. Odds ratio of logistic models predicting children educational enrolment

\begin{tabular}{lll}
\hline & Combined sample & \\
\hline Parental Migration Status (non-migrant as ref) & & \\
Father migrant & $2.49^{* *}$ & {$[1.190-5.205]$} \\
Mother Migrant & 1.41 & {$[0.845-2.370]$} \\
Return Migrant Parent(s) & $1.99^{* *}$ & {$[1.189-3.443]$} \\
& & \\
Control Variables & & \\
Children: & & {$[0.091-1.887]$} \\
Older-cohort children & $0.13^{* * *}$ & {$[0.892-1.671]$} \\
Female & 1.22 & \\
& & \\
Household: & & {$[0.501-1.040]$} \\
Income Status (high as ref) & & {$[0483-1.310]$} \\
$\quad$ Middle & 0.71 & \\
$\quad$ Low & $0.80^{\sim}$ & {$[0.786-1.652]$} \\
Perception of Quality of Life (better as ref) & & {$[0.676-1.668]$} \\
$\quad$ Neutral & 1.14 & {$[0.652-0.876]$} \\
$\quad$ Worse & 1.06 & {$[1.018-1.580]$} \\
Number of adults in the household & $0.77^{* * *}$ & {$[0.397-0.857]$} \\
Number of children in the household & $1.27^{*}$ & {$[1.020-2.116]$} \\
Has younger sibling(s) & $0.58^{* *}$ & {$[1.526-5.052]$} \\
Has older sibling(s) & $1.47^{* *}$ & {$[0.910-1.757]$} \\
Household head's education (senior high \& above) & $2.78^{* * *}$ & 1.26 \\
Household head (female) & 1.00 & $0.985-1.016]$ \\
Household head's age & 1031 & \\
\hline$N$ & &
\end{tabular}

$95 \%$ confidence intervals in brackets

$\sim p<0.10,{ }^{*} \mathrm{p}<0.05,{ }^{* *} p<0.01,{ }^{* * *} p<0.001$ 
Table 3. Odds ratio of logistic models predicting educational enrolment of younger children and older children

\begin{tabular}{|c|c|c|c|c|}
\hline \multirow{2}{*}{ Parental Migration Status (non-migrant as ref) } & \multicolumn{2}{|c|}{$\begin{array}{c}\text { Younger cohort } \\
\text { sample }\end{array}$} & \multicolumn{2}{|c|}{$\begin{array}{l}\text { Older cohort } \\
\text { sample }\end{array}$} \\
\hline & & & & \\
\hline Father migrant & 0.60 & {$[0.255-1.430]$} & $5.91^{* * *}$ & {$[2.813-9.443]$} \\
\hline Mother Migrant & $0.38^{* *}$ & {$[0.180-0.815]$} & $2.75^{* *}$ & {$[1.413-5.369]$} \\
\hline Return Migrant Parent(s) & $0.45^{*}$ & {$[0.220-0.931]$} & $3.68^{* * *}$ & {$[1.933-7.304]$} \\
\hline \multicolumn{5}{|l|}{ Control Variables: } \\
\hline Children (female) & 1.11 & {$[0.634-1.939]$} & 1.36 & {$[0.897-2.063]$} \\
\hline \multicolumn{5}{|l|}{ Household: } \\
\hline \multicolumn{5}{|l|}{ Income Status (high as ref) } \\
\hline Middle & 0.84 & {$[0.442-1.617]$} & 0.86 & {$[0.430-1.706]$} \\
\hline Low & 0.68 & {$[0.310-1.499]$} & $0.61^{*}$ & {$[0.363-1.031]$} \\
\hline \multicolumn{5}{|l|}{ Perception of Quality of Life (better as ref) } \\
\hline Neutral & 0.91 & {$[0.491-1.699]$} & 1.19 & {$[0.722-1.949]$} \\
\hline Worse & 1.82 & {$[0.767-4.307]$} & $0.58^{\sim}$ & {$[0.293-1.101]$} \\
\hline Number of adults in the household & 0.94 & {$[0.735-1.215]$} & $0.66^{* * *}$ & {$[0.525-0.832]$} \\
\hline Number of children in the household & 0.87 & {$[0.593-1.281]$} & $1.40^{*}$ & {$[1.025-1.907]$} \\
\hline Has younger sibling(s) & 1.05 & {$[0.489-2.267]$} & $0.42^{* * *}$ & {$[0.251-0.710]$} \\
\hline Has older sibling(s) & 1.43 & {$[0.742-2.760]$} & $1.96^{* *}$ & {$[1.182-3.241]$} \\
\hline Household head's education (senior high/above) & 1.21 & {$[0.570-2.584]$} & $4.78^{* * *}$ & {$[2.216-10.31]$} \\
\hline Household head (female) & 1.00 & {$[0.558-1.825]$} & 1.31 & {$[0.833-2.046]$} \\
\hline Household head's age & 1.00 & {$[0.970-1.029]$} & 1.00 & {$[0.978-1.016]$} \\
\hline$N$ & 560 & & 471 & \\
\hline
\end{tabular}

$95 \%$ confidence intervals in brackets

$\sim p<0.10,{ }^{*} \mathrm{p}<0.05,{ }^{* *} p<0.01,{ }^{* * *} p<0.001$ 